\title{
Money Trouble in an African Art World: Copyright, Piracy, and the Politics of Culture in Postcolonial Mali
}

\author{
Ryan Thomas Skinner \\ The Ohio State University \\ skinner.176@osu.edu
}

\begin{abstract}
In this essay, I present a genealogy of copyright and its criminalized corollary, piracy, through an emergent politics of culture in Mali, West Africa, over the past half-century. Emphasizing the production, circulation, and performance of music, this history reveals the longstanding, though steadily deepening social, political, and economic precarity that has shaped the subjectivity of the contemporary Malian artist. Framed as a critique, the essay brings the past to bear on the current era of neoliberalism and the anomic disjuncture between an unregulated free market and the disciplinary state institutions that neoliberal governmentality has produced within the Malian culture economy.
\end{abstract}

Keywords: cultural policy, postcolonial history, intellectual property, music piracy, Mali

\section{Money Trouble}

In November 2006, the Triton Stars, an aspiring Malian dance band, finished up a four-day run at Studio Bogolan in Bamako, Mali's capital along the upper Niger River. The recordings were for the band's second album, a follow-up to their first release, Immigration, which had been on the market since January of the same year without any sales to speak of. In an effort to rejuvenate the band's prospects, producer Racine Dia decided to re-release the first album in January 2007, to be followed soon thereafter by the second (as yet untitled) album, building on the anticipated success of the first. The problem, Dia told me, was that nobody in Mali knew the Triton Stars. They didn't have tògò ("a reputation") in the city. To rectify this, the group would play a series of weekly concerts in December, free of charge.

On Friday, 8 December, audience members - including friends of the band, shoppers from the nearby Sokoniko market, and a large contingent of neighborhood youth - sat noisily on plastic chairs laid out on a small grassy field in front of the concrete stage. Others stood behind them, or along the wall marking the perimeter of the Centre de Recherche Culturelle et Artistique, a privately funded cultural center. At 9:30 pm, the Triton Stars took the stage, right on schedule, kicking off with a track from their new album, a piece called "Wariko" ("Money Trouble"), a hard-edged and fastpaced Afropop arrangement. Lyrically, the song addressed a theme to which everyone present could relate: the socioeconomic precarity inherent to a loosely regulated and generally inequitable cash economy. In the opening verse, lead singer Karounga Sacko belted out the following lines: 
I ma don tile min ye

("Don't you know that the sun today")

tile feri feri?

("is a very hot sun?")

Kow bèè dalen wariko de la

("Everything is tied to money trouble")

Aaaa! Wari ma nyi de

("Ahhh! Money is not good")

Balima dama ye nyògòn na bila

("Family members are beset by dispute")

ko nin kun ye wariko

("because of money trouble")

Furunyògòn dama ye nyògòn na bila

("Married couples are beset by dispute")

ko nin kun ye wariko

("because of money trouble")

Siginyògòn dama ye nyògòn na bila

("Neighbors are beset by dispute")

ko nin kun ye wariko

("because of money trouble")

Jènyògònmògòw ye nyògòn janfa la

("Close friends have betrayed each other")

Aaaa! Wari ma nyi de

("Ahhh! Money is not good")

Nè dun siran na

("As for me, I am afraid")

Nè bè siran wari nyè

("I am afraid of money")

A ye furu sa

("It kills marriage")

During my fieldwork in Bamako (2005-2007), the phrase "wariko", much like the incessant heat of the afternoon sun (as Sacko poetically notes above), was ubiquitous. When a roving hawker entered into a family compound in hopes of selling his wares, he was almost always greeted with a polite "wariko", meaning: "Sorry, we don't have money to spend today". When a friend or a relation approached her companion, brother, or sister for some extra cash to get through the week, she often heard "wariko" in response, implying: "I'd like to help, but I have the same problem right now". In the market, the phrase echoed in the mouths of peddlers and hagglers with such redundant frequency, that it became a sort of vocal leitmotif in Bamako's urban soundscape. Echoing this refrain, Sacko probed its psychosocial dangers. Because of money trouble, extended families, neighbors, siblings, and close friends are embroiled in argument and betrayal. Money kills marriage and inspires fear. It threatens both self and society. 
Later in the show, the subject of money trouble returned, this time in the words of two MCs (animateurs), whose stage patter between songs playfully referenced the precarious livelihoods of professional artists in Mali. "Everyone will get together to buy this cassette", one of the MCs announced. "So, what's the problem? You only need to listen to the first track on Side A. Honestly, you will hear people making noise! When that track is playing, you will be pleased." What, then, was "the problem"? As the second MC explained, it was not simply social and aesthetic; it was also, and perhaps more urgently, political and economic:

This cassette, it's good from start to finish. If you know it, you know what's in it. What do we want from you? You can tell others about it. I know it. [The Triton Stars] are young musicians, who are on the rise. The problem these artists face, though, is cassette piracy. If you haven't bought this cassette, if you want these musicians to advance... if you buy this cassette, make your best effort [to buy the one] with the sticker on it and the BuMDA [Bureau Malien du Droit d'Auteur] label. That's the only way artists can make a living.

In this essay, I historicize this complex problem by interrogating the salient and oppositional forms wariko takes within the Malian culture industry: copyright (droit d'auteur) and piracy. ${ }^{1}$ I also consider, like Sacko in his song, the socioeconomic repercussions of this "money trouble" in the working lives of professional artists. Yet, as the Triton Stars' concert made clear, such troubles are not just about money; rather, they index a pervasive sense of precarity that triangulates social, political, and economic uncertainty for which money, and its widespread lack, is the privileged sign. ${ }^{2}$ As sociologist Franco Barchiesi describes, in a poignant critique of (neo)liberal economic rationality, "precarity' transcends the problematics of employment insecurity [glossed here as "money trouble"] in conventional policy and sociological debates, emphasizing instead the crisis of work and of an entire normative and symbolic universe that, during the decades of global neoliberal hegemony, has heavily come to rely on the employment imperative" (2012, my emphasis). For many artists, the professional precarity signified by wariko has a clear source: music piracy. "The problem", the MC said, "these artists face". It is this qualification of piracy as an objective and strongly negative truth - what Barchiesi calls a "normative and symbolic universe" - that this essay seeks to historically contextualize and, in doing so, problematize.

As the scene above indicates, appeals to confront the problem of piracy and affirm the status and identity of local artists as rights-bearing subjects resound within the Malian public sphere. Such arguments echo anxieties about the social and economic value of music in an era of privatized markets and decentralized politics, a sentiment expressed when the MC spoke, from the stage of a private cultural center, of "the only way artists can make a living" (my emphasis). Through such claims on socio-musical justice, a contemporary discourse of neoliberal governance takes shape around the concept of "culture", defined as an expedient object of curatorial and commoditized expression (Yudicé, 2004). Copyright and its ubiquitous infringement, piracy, represent the normative and aberrant forms through which culture is produced and policed in Mali, as elsewhere (see Karaganis 2011); that is, they are the categorical means by which "governmentality" - the regulatory and disciplinary politics of population management and control in modern states (Foucault 2007) - operates as "cultural policy" under the global sign of neoliberalism (see Guilbault 2007).

In practice, however, the politics of culture in Mali has succeeded neither in securing the legal and pecuniary interests of musicians nor in stemming the unauthorized reproduction of musical works. This perceived failure of neoliberal governance manifests in what I have elsewhere called an artistic "crisis of political subjectivity" (Skinner 2012a), in which musicians, caught between a dysfunctional state and an informal economy that flourishes in its midst, struggle to sustain a viable professional status and identity. In what follows, I put these artistic struggles into historical relief by tracing a genealogy of copyright and its criminalized corollary, piracy, through an 
emergent politics of culture in Mali. This history reveals the longstanding, though steadily deepening social, political, and economic precarity that has shaped the subjectivity of the postcolonial Malian musician. This essay is, thus, a particular history of wariko as experienced by musicians in the Malian art world (see Becker 1982) from the era of independence to the present. It aims to bring the past to bear on this current era of neoliberalism and the pervasive "money trouble" it produces by interrogating the governmentalization of culture as a regime of rights and discipline in postcolonial Mali. As a cadential counterpoint, I conclude with a short reflection on what I will call "nongovernmental culture", or the forms of expression that articulate outside - and often in violation - of the disciplinary institutions of neoliberal governmentality. Yet, as we shall observe, Bamako's non-governmental culture can only be fully understood in relation to the history of cultural governmentalization in postcolonial Mali, to which I now turn.

\section{Artistic Rights and Labor in Post-Independence Mali}

In 1957, artists working in the French Soudan (now Mali) and other French colonies were allowed to join the Société des Auteurs, Compositeurs et Editeurs de Musique (SACEM), a French agency that managed the licensing of artistic works and the collection and distribution of royalties for affiliated artists (Diakite 2006: 54; see also Laing 2004: 71-2). This imperial affiliation did not last long. Following independence three years later, all music produced in Mali, in line with the new nation's policy of cutting institutional ties with its former colonizer, fell under the purview of the state. Up until 1977, Mali did not have any codified copyright law or bureaucratic mechanism for royalty distribution. This meant, in practice, that the postcolonial state could act as the sole arbiter of domestic cultural production, distribution, and exploitation. In 1962, Mali did, however, ratify the Berne Convention in nominal deference to international intellectual property law and, the same year, the government signed the continental accord creating the Organisation Africaine de la Propriété Intellectuelle (Cissé and Traoré 2001: 7). In 1963, Mali re-affirmed its commitment to "the harmonization of copyright law in Africa" at a UNESCO-sponsored meeting of the International Bureau for the Protection of Intellectual Property in Brazzaville but argued that such legislation should "take local context and popular opinion into account" (Ntahokaja 1963: 252$253),{ }^{3}$ thereby affirming the authority of individual African states to legislate intellectual property as they saw fit. Despite the official public rhetoric of international and continental agreement, copyright in Mali remained un-codified and subject to arbitrary state interpretation for nearly two decades.

As copyright goes, so go the artists. In the 1960s, musicians in Mali were beholden to the state as clients of a nationalist politics of culture, though, until 1966, they were not employed by the state. For the most part, artists worked informally, living off a share of ticket sales from concert performances, without a décision d'embauche ("an employment contract") (P. Dembelé 2007). Their musical labor (performed and recorded) was considered property of the state and was described, under the regime of Modibo Keita (Mali's first President), as fasobaara ("work for the nation"), in Bamanakan, Mali's lingua franca. In the early-1960s, this could sometimes mean unpaid labor, described in terms normally associated with colonial rule: forèsèbaara and diyagoyabaara ("forced labor" and "whether-you-like-it-or-not work"). "They couldn't pay us", recalls Nfa Diabaté, a retired member of the National Instrumental Ensemble, "so they called it fasobaara" - a postcolonial expression of wariko in the 1960s Malian art world (D.N. Diabaté 2006; see also Amselle 1978: 343, 348).

And, as artists go, so goes their work. In the post-independence era, musical recordings were made and archived at Radio Mali, the single, state-owned media outlet that housed the country's only recording studio (see Diawara [Mamadou] 1997). These recordings were, for the most part, propagandistic in terms of content, with themes that emphasized nationalist use value, including comparisons of the modern nation-state to the pre-colonial Mali empire Maliba ("Great Mali); calls for newly 
ordained Malian nationals displaced within the former French empire to return home ("Yan Ka Di", Here Is Good); and appeals to work for the homeland ("Fasobaara", Nation Building). ${ }^{4}$ Exchange value was a lesser concern. Recordings of such nationalist music (see Skinner 2012b) were made principally for radio broadcast. Long play pressings of state-sponsored Malian groups did not appear until the late 1960s and were not widely distributed until the early 1970 s. ${ }^{5}$ By contrast, foreign produced records had long been in circulation (since at least the 1940s), especially in the capital, Bamako, where such regional and global sounds were coveted commodities within an urban popular culture that thrived throughout the 1950s, 60s, and 70s (Diawara [Manthia] 1997; Skinner 2011).

A disjuncture thus emerged between the circulation and consumption of national and foreign music that, under the increasingly authoritarian rule of the single-party state in the late-1960s, also marked the fault lines of official and unofficial culture. As a young activist of the ruling party asked in December 1967: "Does the Malian revolution need James Brown [or] Johnny [Halliday]... to fill the catalog of its National radio"? ${ }^{6}$ Perhaps not; yet, despite efforts to inhibit foreign (which usually meant Western and neo-colonialist) cultural influence (see, for example, Arnoldi 2006: 60), such recordings continued to resonate within Bamako's urban soundscape. ${ }^{7}$ For Malian artists, this cleavage between the national and the popular, the official and the unofficial, became a source of great frustration. With their domestic labor beholden to a single venue of broadcast distribution at the national radio, and without any legal right to their recorded work in Mali, the subaltern status of their cultural labor became patent. Internationally renowned musician Sorry Bamba's autobiography (Bamba and Prévost 1996) recounts his attempt to procure copies of an album recorded on the occasion of Mali's tenth anniversary of independence for his state-sponsored band, the Orchestre Régional de Mopti (1970). His narrative captures the perceived injustice of Mali's centralist policy toward cultural production and ownership:

Each of the musicians was looking forward to receiving a copy of the disc. But, when they saw the Youth Director giving one disc to the authorities in Mopti and only one for the entire Orchestra, they were shocked by the deception! This meant that just one disc was to be shared, like a wafer, among all of the musicians in the Orchestra!

Such pettiness nauseated me to such a degree that I lost interest, given the circumstances, in this recording. And yet, this disc represented my own research and adaptation, backed up, of course, by the competence of the musicians. If copyright is respected in other countries, here, it does not exist. I know this well, because I have been a member of SACEM since 1968 and released a number of albums in Côte d'Ivoire.

In Mali [in the 1960s and 1970s], all albums were the property of the state. It was not even possible for a composer [auteur-compositeur] to reclaim the studio tapes of his own works if the Youth Ministry decided to keep them for a recording. Radio Mali was not permitted to give out a copy to these artists [auteurs].

In the face of this injustice, a friend of mine managed to acquire some of my recordings that were being broadcast on the Radio Mali airwaves. It was only because of this effort, that I had the immense joy of being able to possess just a few of my own works (1996: 134)!

As Bamba describes, Malian artists' access to their recorded works through the 1960 s and into the 1970s was restricted by a highly centralized cultural economy and subject to the arbitrary decisions of local and national authorities, subverted only by the surreptitious pirating - to complicate the shades of illegality the contemporary term piracy implies - of the artists' own music broadcast on the national airwaves.

These frustrations about cultural ownership, production, and circulation coincided with a coup d'état in November 1968, the immediate aftermath of which (following a brief period of hopeful jubilation, see Sanankoua, 1990: 55) exacerbated artists' woes. After the coup, all cultural troupes, orchestras, and ensembles were disbanded by the ruling military junta, the Comité Militaire de Libération Nationale, and remained so for 
more than a year (A. Traoré 2007). Without salaried contracts, given their status as unofficial agents of national culture under the previous regime, Malian artists were confronted by two stark choices: leave the country and embark on an indefinite exile, or stay, weather the storm of military rule, and hope for the best. Many left. Abidjan, the booming capital of Côte d'lvoire, Mali's richer and more liberal (but no more democratic) southern neighbor, became the destination of choice. Sorry Bamba, himself recently returned to Mali from Côte d'Ivoire (where he had fled from the tyranny of Modibo Keita's revolutionary socialism in the late-1960s), described sentiments shared by many Malian artists in the post-coup years:

Suddenly, I understood the scope of a Coup d'Etat. All regime changes shake people's spirits. Everyone must learn to observe the new methods of those who claim power... What's more, I must fight vigorously against the despair that surrounds me, faced with so much aggression, so uncommon in the artistic community. Why so much hostility toward the pioneering musicians of Malian music? Our music, born with our country's Independence, does it not belong to everyone? If, in my own country, creativity no longer has a place, so much the reason to get back on the difficult path of exile (Bamba and Prévost 1996: 112).

The 1970s Ivoirian economy, bolstered by lucrative cocoa and coffee exports and President Houphouët Boigny's clientelist politics, provided for a strong patron class in Abidjan. Some of these wealthy and well-placed entrepreneurs had personal ties to Mali and favored the arts, like Souleymane Koli, who recruited expatriate Malian artists into the famed Ballets Koteba (see Skinner 2004: 144-145). Flush with cash and a fondness for popular culture, Abidjan quickly emerged as the capital of the regional music industry. "[M]usicians came from the four corners of francophone Africa to try their luck in Côte d'Ivoire", writes Chérif Keïta, in his important biography of Malian singer Salif Keita, one of Abidjan's seminal figures in the late 1970s and early 1980s. "This situation imposed a new kind of rationality on the African artist, who could no longer hope to survive by courting local audiences or counting on the patronage of the State" (2009: 76). In Abidjan's highly competitive, market capitalist music scene, "artistic rationality" meant seeking out patrons, cutting records, and embarking on tours in the regional, continental, and increasingly international African cultural industry. Back in Bamako, the state oligarchy (now in civilian guise as the Union Démocratique du Peuple Malien) maintained its grip on cultural production, patronizing select groups that practiced the art of political flattery (2009: 37); though, by the end of the 1970s, political and economic changes were underway that, within a decade, would herald the end of the centralized and authoritarian regime itself (cf. Pauthier 2012).

\section{The Neoliberal Turn}

In 1977, Mali enacted its first copyright law (77-46/CMLN), providing for the protection of the "literary and artistic property" of culture producers, or "authors." This was followed in 1978 by the creation of the Bureau Malien du Droit d'Auteur (BuMDA) whose mission was to "defend the intellectual, moral, and pecuniary interests of authors and their rights therein" (Cissé and Traoré 2001: 5). However, without a clear mandate to enforce intellectual property rights, and given the persistence of statist sponsorship of the arts through the mid-1980s (despite increasingly austere socioeconomic conditions), real changes in artists' professional status and identity (though not necessarily those envisaged by the laws) would not come until the mid-1980s. In July, 1984, in a brochure commemorating the closing of the $8^{\text {th }}$ Biennale Artistique et Culturelle, a state-sponsored biannual cultural festival, the Director of Arts and Culture, an adjunct to the Minister of Culture, prepared a series of responses to questions concerning the event's successes and failures. ${ }^{8}$ His response to the fourth, penultimate question was revealing and prescient given the changes occurring not only in the Malian culture economy but in the political economy of the post-colony more broadly. 
4.) Monsieur le Directeur, you know better than anyone else that broadcast and circulation are the best ways to encourage cultural creation, yet the works from the last Biennale were not widely broadcast or circulated. Why?

RESPONSE : $4^{\text {th }}$ QUESTION

I am obliged to say what many people would not like to hear. Nonetheless, it's the sad reality. In fact, the reason these works have not been broadcast and circulated is due to a lack of means. And as you have so well put it, the broadcast and circulation of these works is our objective. But it is necessary for us to recognize that we do not possess for the moment the national structure allowing [us] to broadcast and circulate works not only from the biennales, but those of our different artists in a general manner...

You see, as our proverb says so well, "when you sweat in the rain, no one notices" [quand on sue sous la pluie, les gens ne peuvent pas s'en rendre compte]. ${ }^{9}$ But I have to say, to conclude with this question, that the solution to the problem of broadcast and circulation of our artists' works in general and of those from the Biennales in particular, can only be found in the creation of a production facility for cassettes and [vinyl] discs in Mali. Thus, we call on our businessmen both in and out of the country to help us to definitively resolve this thorny problem that dangerously hinders artistic creation in our country, not to mention the danger of seeing our artists emigrate to find a record company in the best of cases, and, in the worst of cases, to find themselves estranged from the fruits of their labor by the illicit production of discs and cassettes (my emphasis).

This question/answer passage effectively captures the shifting socio-political position of Malian artists and the changing perceptions of their work in the mid-1980s. The question succinctly makes the point that proponents of free culture (Lessig 2004) have long advocated: that cultural creativity benefits from greater public access to cultural products, in this case through increased broadcast and circulation of recorded works on the airwaves and in the marketplace. The response, however, signals the new orientation of Malian cultural policy - toward an emergent neoliberal governmentality - in a time of socioeconomic austerity: the state, no longer possessing the means to manage the production and distribution of cultural works, must privatize public culture. Written in July, in the midst of the rainy season, the Director describes the state's anxiety - sweating in the rain - about producing and promoting new cultural works and calls on "our businessmen both in and out of the country" to invest in the development of a private culture industry. This call to liberalize Mali's stagnant culture economy responds to two problems that "dangerously hinder artistic creation": 1.) emigration of national artists (discussed above), and 2.) "the illicit production of discs and cassettes" (or what would later be called, simply, piracy), the latter being the worst of cases, suggesting the emergent state of the counterfeit market at the time.

As this statement was written, major changes in the social, economic, and political character of the arts in Mali were already underway and would accelerate by decade's end. In June of 1984 (a month before the Biennial), a law was passed (84-26/AN-RM) to replace the 1977 ordinance defining "artistic and literary property" in Mali. The updated document more specifically elaborated the notion of copyright and included a statement outlining what constitutes illicit reproduction of copyrighted material (articles 31-36) and a list of sanctions for various infractions (articles 135-148) - making media piracy an object of governmental intervention. Two years later, in March of 1986, the government passed legislation (86-13/AN-RM) to reform the code of commerce, effecting a radical liberalization of the national economy, largely in response to the exigencies of IMF-sponsored Structural Adjustments Programs (SAPs), including the privatization and liquidation of many state-owned businesses - making public sector retrenchment an object of governmental intervention. Enter the private sphere. In 1988, a French entrepreneur, Philippe Berthier (who had become disillusioned with the punk rock scene in Lyon, where he managed a record store, and decided to turn his sights toward Africa) moved to Bamako, where he set up Mali's first private multi-track recording studio. In 1989, Berthier opened the country's first cassette duplication 
factory, which, along with his studio, formed the base of his new company, Ou Bien Productions (Maillot 2002). A private music industry was, thus, born in Mali, founded on the codification of copyright, the criminalization of media piracy, investment in private infrastructure, and a radical divestment in public institutions, including state-sponsored artistic groups and festivals.

Yet, expectations of a rationalized cultural economy soon encountered the limits of neoliberal governmentality within the fragile Malian political economy. On 26 March 1991, the dictatorial regime of Moussa Traoré fell to a coup d'état, following months of protests in the capital city. As an interim government stepped into power, civil society expanded, signaled by the mushrooming of private radio stations in Malian towns and cities (Couloubaly 2004: 24). Often cited as evidence of a new democratic spirit surging throughout the continent in the early 1990s, cultural authorities perceived the proliferation of these new media outlets with trepidation. The BuMDA, which was given further autonomy and greater authority to represent and defend the pecuniary interests of artists in a 1990 ordinance (90-55/P-RM), witnessed what it viewed as an unprecedented affront to artistic copyright with the sudden increase in private radio broadcasts. Recorded music of all kinds filled the airwaves as new stations vied for listening publics (see Tower 2005). However, no royalty payments were made for the broadcast of these recorded works, setting an unlawful precedent for private radio broadcast in Mali that continues to this day (M.M. Diakité 2007). Since 1984, in accordance with article 29 of the intellectual property law 84-26/AN-RM, the Office de Radiodiffusion et de Télévision du Mali, has paid a fixed annual sum of 5 million CFA $(\$ 10,000)$ to the BuMDA, a fee recently (2002) complemented with a further 100 million CFA (\$200,000) annual government subsidy (Couloubaly 2004: 169). A 1994 amendment (94-043) to the 1984 copyright legislation (84-26/AN-RM) requires private radio stations to pay a similar flat annual fee for the use of musical works; though, such payments remain disputed and, thus, commercial radio broadcasts in the private sphere remain, officially, unlawful.

Where media goes, the musicians follow. From the late-1980s, many statesponsored artists were offered severance benefits, including early pensions for those who qualified, in an effort to reduce civil servant expenses in line with SAP protocols. As a matter of policy, the process of cultural privatization had been underway since the late-1970s, spearheaded by Minister of Culture Alpha Oumar Konaré. Artists departing the state-sponsored orchestras and ensembles at this time (including popular divas Kandia Kouyaté, Amy Koita, Tata Bambo, and Nahawa Doumbia from the Ensemble Instrumental National) formed new groups and introduced the notion of the solo artist to regional audiences (B. Maiga 2011). Bolstered by the presence of a domestic and private (if limited) record industry (that is, Ou Bien Productions), the decline of Abidjan as a regional center of music production, an influx of foreign capital in the form of World Music (then, a new concept; see Feld 2000: 146-151), and the subsequent proliferation of private radio following the 1991 coup (which did much to promote the work of Malian artists, despite official accusations of copyright infringement), many musicians' careers did, in fact, take off. This has been described as a period of "effervescence" in Malian music (Touré 1996: 98). No longer bound to the state, artists were now free to explore private enterprise in an unfettered capitalist terrain. But, just as conditions were ripe for the rise of prominent solo artists in the early-1990s, so too were circumstances ideal for the further criminalization of the Malian culture economy (see Bayart et al. 1999) and a parallel effervescence of neoliberal wariko ("money trouble"), in the artistic community.

When musicians go, the state turns its back. In many ways, this criminalization begins, not with piracy, but with the state's Voluntary Early Retirement (VER) programs, first authorized in August 1986. ${ }^{10}$ Between 1987 and 1989, the USAID (United States Agency for International Development) sponsored a pilot program to offer fonctionnaires ("civil servants") a single lump-sum pension before their 
anticipated retirement. 644 people left the civil service during this first wave of VER. A second wave, which transpired sporadically between 1991 and $1995,{ }^{11}$ saw 5023 state employees leave, including subventionnaires ("subaltern civil servants"), a category which included many state-sponsored artists. The lump sum offered to fonctionnaires was $2,500,000$ CFA $(\$ 5,000)$. Subventionnaires received 1,500,000 CFA (\$3000) (B. Diarra 2008). In the early 1990s, under the leadership of now-President Alpha Oumar Konaré, the state encouraged artists in particular to opt for the VER, using their pension as start-up capital to form new orchestras and ensembles (A. Fofana 2008). While many private music groups did form during the 1980s and 1990s, I found no evidence that VER funds contributed to the formation of any orchestra or ensemble. Those groups that did emerge and succeed outside the aegis of the state benefited from the renown of already-established artists, as with the solo divas of the National Instrumental Ensemble mentioned above (see Durán 1995). Most artists who opted for VER saw their capital disappear into extant debt, family obligations, and everyday expenses. If private sector aspirations ever were envisioned, they soon became the source of bitterness, despair (J.M. Diabaté 2006; A. Fofana 2008).

\section{Anarchy and Control}

As state authorities pushed artists into a growing private sector, they did little to monitor or regulate the emergent culture economy that sector fostered. Even so, state discipline, the punitive corollary to privatization, was not entirely absent and, in hindsight, seems merely to have been deferred. In June of 1993, the BuMDA conducted a police seizure operation in media markets throughout Bamako and collected 39,500 cassettes, of which 12,274 were determined to be pirated. (It is not clear what happened to the remaining 27,226 legitimate cassettes.) As Mandé Diakité reports, "[t]his action was condemned by the authorities, and 'the fight against piracy', judged inopportune, was suspended until September 1994 due to the insecurity that reigned over punitive actions of any kind in Mali" (2006: 4). In an effort to secure the legitimacy of the new democratic Republic and distance themselves from the recently ousted junta, government authorities under the leadership of President Alpha Oumar Konaré strategically refrained from any overt acts of state intervention. Indeed, after two decades of political misrule (Diarrah 1991) the state had become a conspicuous target of popular animosity. As Diakité describes:

After the coup d'état [in 1991], there was a period when the authorities could not collect taxes. Why? Because, at the time, there was a sense of overwhelming freedom [la grande libérté]. People would say, 'I don't respect the State. I don't respect the actions of the State...' Well, each time that we [at the BuMDA] attempted to conduct seizures [of pirated media], we were told 'no, all such operations are prohibited'. Thus, when [democracy and economic liberalization] came, they manifest themselves as a rejection of authority, [and] this rejection spread to all sectors [of society]. (M.M. Diakité 2007).

"Henceforth", Diakité writes elsewhere, "piracy would take root with impunity and become habitual among merchants", adding, more polemically, that "over the course of three years, the pillaging of artists and producers would occur everywhere and at all times without risk to the offenders" (Diakité 2006: 4).

While Diakité's passionate and unambiguously critical take on this history of piracy is clearly driven by his longtime work with the Malian Copyright Office, his observation of the increasingly habitual nature of economic informality within an un-regulated media marketplace is important. This is because habit engenders assumptions of natural conditions and a certain acceptance of things as they are, however disquieting, dangerous, or destructive those things may be. In the context of laissez-faire capitalism, media piracy did, as Diakite argues, become an entrenched fixture of the Malian culture economy. Yet, as described above, this cultural economic condition - of the counterfeit reproduction and sale of commercial media - was preceded by the habit of public divestment in the arts, in line with prescribed SAPs, combined with the 
similarly structured habit of governmental deregulation - to say nothing of the habits of (re)production and circulation that the media themselves produced (see Larkin 2008). Later, a habit of periodic police discipline would develop to confront the counterfeit culture economy; thus, criminalizing piracy, too, became a habit. In other words, the habitual problem of piracy is rooted in the paradigmatic and hegemonic habits of neoliberalism: divestment, deregulation, and discipline. The result is a postcolonial culture economy that is torn between perceptions of anarchy and prescriptions of control (Comaroff and Comaroff 2006), a position that only serves to further entrench neoliberal habits, not redress them.

These habits would gain steam through the 1990s. In March of 1994, the legal mandate of the BuMDA was once again strengthened by an amendment (94-043/ANRM) to the 1984 copyright law (84-26/AN-RM). The same year, music critic Banning Eyre reports that the Malian government made an unsuccessful attempt to shut down Radio Kayira, a private Bamako-based radio station that was fiercely critical of the government (2000: 198), on the grounds of copyright infringement (M.M. Diakité 2007). The following year, global music production house EMI, affiliated with Ou Bien Productions since 1992, closed its operations on the continent (with the exception of South Africa). Ou Bien chief Phillippe Berthier, lacking a strong international backer, turned to local entrepreneur and Grammy Award-winning musician, the late Ali Farka Touré (Maillot 2002). With Touré's partnership, a move that bolstered the local legitimacy of this previously foreign-owned company, a new business, Mali K7 (pronounced, in French, "Mali cassette"), was created. Yet, this symbolic act of cultural political control, providing an air of authenticity to Mali's small private record industry, materialized on the margins of a marketplace in which the perceived anarchy of media piracy predominated.

Banning Eyre's account of record producers' dealings with cassette piracy during his six-month research trip to Bamako in 1995-6 describes the industry's extraordinary (and perhaps foolhardy) attempts to negotiate this disjuncture in the production and circulation of commercial culture, asserting control in the midst of anarchy:

The moment a new cassette goes public, its producer enters a race with time. He must hustle to sell as many legal cassettes as possible before cheaper pirate copies flood the market. The difference between a two-week and a three-week delay can mean thousands of legitimate sales, maybe tens of thousands in the case of a major artist (2000: 198-199).

Eyre goes on to cite Oumou Sangaré's husband and manager, who presents his own homegrown tactic to combat piracy: "Most of the pirate copies come up from Guinea, and when the rains start, some of the main roads close. That might delay the arrival of pirate copies a week or more" (2000: 199).

Such dramatic efforts (timing a release for the onset of the rainy season) might make sense for an artist of Sangaré's stature, who, with domestic media sales in the tens (if not hundreds) of thousands of cassettes and compact discs, has much to lose to counterfeit commerce. For most Malian musicians, however, the media market, from which earnings are either limited or non-existent, is of far less concern than the highly competitive live music scene in the capital, Bamako, and the possibility for tours and recording contracts abroad, in Europe and the United States. For these artists, local live performances are, at best, a way to promote themselves and their work in hopes of being discovered by industry-connected World Music enthusiasts, who, over the past decade, have listened in to Bamako's popular music culture with growing interest (see, for example, Hammer 2005). At worst, such performances represent a recurrent source of personal and professional discouragement.

While living in Bamako in late 1990s and early 2000s, I worked closely with kora (21-stringed Mande harp) virtuoso Toumani Diabaté, whose group, the Symmetric Orchestra, played every Friday at a popular (but now defunct) nightclub, Le Hogon. For 
Symmetric members, the professional significance of these gigs had little to do with earnings (with a nightly take per musician of around \$10); more important was the possibility of joining their globetrotting bandleader on one of his many concert tours abroad. Yet, to their recurrent dismay, Diabaté would leave with his Mande Jazz Trio (still together and very popular at the time), fellow kora master Ballaké Sissoko (with whom he had just recorded an album), or foreign collaborators like blues legend Taj Mahal (whose collaboration with Diabaté produced a global bestseller). ${ }^{12}$ For Bamako bands, like the Symmetric Orchestra, the tantalizing - though rarefied - ideal of a global music career must be weighed against the harsh reality of making-do and getting-by at home, scraping out a meager living at nightclubs and local ceremonies, and waiting for the next chance to get out. ${ }^{13}$ This is, perhaps, the most salient everyday condition of musical wariko ("money trouble") in the late $-20^{\text {th }}$ and early-2 $21^{\text {st }}$ century Malian art world.

Such professional concerns, which emphasize artistic persons over products in an otherwise de-personalized culture economy, have, since the late 1990s, gone largely unacknowledged by state and industry authorities, for whom control over the media market remains the predominant political and economic issue. Foreshadowing the piracy crises of the mid-2000s (see Skinner 2012a: 730-739), Mali K7, still the sole music production house in the country, announced in December 1999 that it would halt its operations and lay off its employees. Discouraged by what he considered to be the state's failure to take action against the influx of counterfeit cassettes in the Malian marketplace, CEO Phillippe Berthier threatened to move his company to neighboring Burkina Faso (Rhythmes 19 1999). Perhaps as a gesture of good faith, the BuMDA, in an act of punctuated police discipline, confiscated and destroyed 60,000 counterfeit cassettes on 1 February 2000 (Cissé and Traoré 2001: 24). Mali K7 reopened its doors the following March (Rhythmes 20 2000). Reflecting on these events, Berthier had the following to say:

It created a national crisis! I made a televised appearance on the evening news, artists organized a march and went to see the Prime Minister at the time, [and] there was a big national conference including producers, artists, police, [and] customs agents. This didn't solve all the problems, but this crisis did raise awareness (Maillot 2002).

This crisis did, in fact, herald a period, however brief, of greater control in the Malian culture economy. In September 2000, ordinance 00-042/P-RM established the BuMDA as a "legal entity" with "autonomous finances" equipped to "organize and represent authors of literary and artistic works as well as their beneficiaries" (articles 1 \& 2). The government thus established a normative institutional framework within which the pecuniary interests of artists could, in theory, be guaranteed and the revenues derived from their works managed and accounted for. In 2002, Seydoni (a Burkina Faso-based record company) opened recording and cassette/CD duplication facilities in Bamako to become the second music production house in Mali (Traoré 2004). The same year, the BuMDA, building on the experiences of copyright agencies in Ghana, Côte d'Ivoire, and elsewhere on the continent, introduced a hologram decal designed to distinguish authentic cassettes and CDs from counterfeits. The stickers would cost 60 CFA (12 U.S. cents) and be applied to album jackets prior to the duplication of the cassettes or CDs. Producers were expected to pay this fee, which would finance artists' copyright allowances. They were also encouraged to produce only as many cassettes and CDs as they expected to sell, given the up-front copyright expense the sticker fees imposed. Yet, despite repeated televised national campaigns to educate the population about the ethics of buying marked legal media - with dramatic claims about the pauperization of artists and the decline of Mali's cultural heritage - the stickers have not proven efficacious in the marketplace (M.M. Diakité 2007).

State authorities have, therefore, turned to other modes of enforcement, largely replacing didactic discipline with martial discipline, manifest, in recent years, in periodic confiscatory raids. These acts of commercial sanction serve to dramatize state power 
while affirming the culture industry's commitment to normative media production and circulation, but they do little to curb media piracy; that is, they have little impact on the non-governmental culture economy: those performances, broadcasts, and exchanges that lie outside the purview of official culture, which neither fully accede to assertions of control, nor wholly ascribe to accusations of anarchy. Rather, the most tangible effects of police raids are exacerbated socioeconomic tensions and, sometimes, violence between the plaintiffs and enforcers of such actions, artists and police, and their criminal targets, media broadcasters and vendors. Politicians, too, are lambasted for their failure to contain and suppress commercial anarchy, or media piracy, when these actions inevitably fail to produce long-term, or even short-term results (see, for example, Skinner 2012a: 734-739). Among these varied casualties of la lutte contre la piraterie ("the war on piracy"), we encounter, once again, the social, political, and economic distortions - the exacerbated wariko - that neoliberal governmentality engenders when applied to the culture economy.

Yet, everyday transgressions of this cultural political hegemony persist, though such persistence should not be confused with outright protest or resistance. In concluding, I will consider, briefly, those practices of ostensible anarchy that arguably account for most cultural production and circulation in contemporary Mali (see, for a comparative study, Karaganis 2011), what I am calling non-governmental culture. I do so by returning to the Triton Stars concert with which I began this essay. To hear this band's performance in the context of the history recounted above is to appreciate the essential ambivalence of a political economy that champions legality at the expense of livelihoods, in which a degraded public sector and an unruly private market necessitate a certain amount of creative infringement of the rule of law - that is, non-governmental culture - in an era of neoliberal governmentality.

\section{A Non-Governmental Mix}

At the end of their set, the Triton Stars invited one of their guest MCs, animateur Man Ken, who, earlier in the evening, had implored the audience to purchase legal copies of the group's new album, to join them on stage for one final song. As a radio and television personality, Man Ken is known for his admiration for and spot-on musical impersonation of Ivoirian reggae superstar Alpha Blondy. "Reggae-manw bè yan wa?" ("Are there any reggae fans here?"), he asked the crowd, eliciting a collective "Awò!" ("Yes!") and a volley of applause. As the noise died down, he proceeded to sing the a cappella introduction to Blondy's "Silence Houphouët d'Or" (1996) - a tribute to the late Ivoirian President, Félix Houphouët Boigny (1905-1993).

Le soleil s'est couché ce matin,

("The sun has set this morning,")

et tous les drapeaux on baissés les yeux

("and all the flags have lowered their eyes")

Devant ce chart d'assaut,

("In front of this tank,")

nos sanglots montent là haut

("our cries rise up on high")

Et seul, dans son linceul,

("And alone, within its shroud,")

Orange, Blanc, Vert...

(“Orange, White, Green...")

With this final, cadenced and color-coded reference to the Ivoirian flag, repeated twice - Orange, White, Green - the Triton Stars joined in with the rocking 
accompaniment - rising and falling between A minor and G Major 7 chords - to Bob Marley's "War" (1976). ${ }^{14}$ "Houphouët! Reveille-toi!" (Houphouët! Wake up!), wailed Man Ken, as the group fell into a sustained reggae groove. "Sabali! Sabali! Sabali! Sabali!" Man Ken sang, repeating the Bamana word sabali ("patience and tolerance") over and over again in an improvised verse. Now, with the crowd on their feet, some spilling over onto the stage, the inspired vocalist layered Marley upon Marley, singing, "Get up! Stand up! Stand up for your right"! At this point, it was no longer apparent what song the group was playing, but it didn't matter - or did it? The mix of Blondy's lament and Marley's musical and lyrical calls to arms offered a clear enough commentary on the civil war raging in Côte d'Ivoire at the time (see McGovern 2011), and the energy of the performance delivered this message with a sonic vibe that brought artist and audience together in soulful communion. But, whose song was it exactly?

The Triton Stars curtain call performance offers a good example of nongovernmental music culture in contemporary Mali. No permissions were sought, nor royalties paid for the copyright protected sounds and lyrics the group performed. The music and words were likely learned through repeated listening to other unlicensed shows, unauthorized broadcasts on the radio, or playback of cassettes and CDs, themselves copied and re-copied at home, or pirated in the marketplace. Yet, this dramatic display of musical and lyrical borrowing, embedding, and layering is haunted by a culture economy that proscribes such practice, an official discourse echoed, ironically, in same group's calls, made earlier in the show, to buy legal cassettes and save artistic livelihoods (their own in particular). So, is this a case of cognitive dissonance, or just plain hypocrisy? With regard to the history of cultural policy and intellectual property in Mali, I would say neither.

When, in the 1980s, the logic of structural adjustment was applied to a postcolonial economy largely divested of its public servants and resources, through gross domestic mismanagement and the global vogue of privatization, the conditions were created for a radical disjuncture between the unregulated free market, on the one hand, and disciplinary state institutions, on the other. In the Malian art world, this division would manifest in the perceived anarchy of the informal marketplace (piracy) and the prescribed control of intellectual property (copyright), resulting in a culture economy of endemic money trouble (wariko). In this context, non-governmental culture, such as the Triton Stars reggae jam, routinely refuses the neoliberal dichotomy of anarchy and control, without, however, altogether refuting its governmentality. In a world of wariko, in which "everything is tied to money trouble", as singer Karounga Sacko earlier proclaimed, groups like the Triton Stars must continually cross the threshold between the licit and illicit, the formal and informal. There, in the everyday interstices of neoliberal governmentality, commitment to copyright and its performative violation are less conflictual than contrapuntal, keeping multiple means to secure artistic livelihoods, however precarious, at play and in the mix.

\section{Endnotes}

${ }^{1}$ In this essay, I use the term "copyright" in the francophone sense of "le droit d'auteur," employed in Mali, a former French colony. "The right of the author" includes both moral and proprietary rights (droits moraux et patrimoniaux), pertaining to the material publication and exploitation (proprietary rights), as well as the personal attribution and integrity (moral rights) of a work (for a definitional history of French copyright, see Latournerie, 2001).

2 For a broad-based ethnographic survey of "money" - its materiality, uses, and troubling effects - in contemporary Mali, see Wooten, 2005. For a more general, comparative discussion of shifting forms and understandings of wealth and value in sub-Saharan Africa, see Guyer, 1995.

${ }^{3}$ I thank Marc Perlman for bringing my attention to this reference. 
${ }^{4}$ See, for example, musical selections included on the two volume release, Epic, historical, political and propaganda songs of the Socialist government of Modibo Keita (1960-1968) (1977).

${ }^{5}$ Ethnomusicologist Graeme Counsel documents a pair of recordings released in 1968 by "Republic [sic] du Mali Radiodiffusion Nationale" in his extensive online "Radio Africa" discography (2012). Elsewhere, Counsel writes that "[c]ommercial recordings were sporadic until the German label, Bärenreiter-Musicaphon, in conjunction with UNESCO and The Malian Ministry of Information, released over a dozen discs in circa (1971). It wasn't until 1973 that the Malian government first released its own material" $(2006,138)$. These recordings sought to sample the regional diversity of Malian cultural expression and likely served as tools of promotion, to "perform the nation" (Askew, 2002) abroad. Examples of such state-sponsored promotional releases include Panorama du Mali (1973) and Regard sur le passé à travers le présent (1973).

${ }^{6}$ Comité revolutionnaire de coordiantion de la JUS-RDA de Bagadadji to Comité Nationale de la Jeunesse (Bamako, 26 décembre 1967, ANM-H FBPN 52/140).

${ }^{7}$ For an artful account of Bamako's "unofficial" postcolonial youth culture, replete with "foreign" sounds, see the photographic work of Malick Sidibé (Mangin, 1998).

8 "Special Clôture", 8 ième Biennale Artistique et Culturelle (1984), edited by the Commission de Presse et d'Information. Un-filed archival document at the DNPC.

${ }^{9}$ In Bamanakan, "Sanjikòròwòsi te dòn".

${ }^{10}$ Journal Officiel de la Republique du Mali: 15 August (1986: 42-44).

${ }^{11}$ Bourama Diarra, the President des Partants Volontaires à la Retraite at the Bourse de Travail (Labor Exchange) in Bamako, states that the VER programs persisted until 1995 (B. Diarra, 2008). My own inquiries revealed VER legislation pertaining to the "second wave" through 1993 (See Journal Officiel de la Republique du Mali: 28 February (1991: 155-58); 15 March (1991: 167); 15 October (1992: 694); and 15 April (1993: 258).

${ }^{12}$ Albums associated with Diabaté's internationally touring groups in the 1990s include the Mande Jazz Trio's Djelika (1995), New Ancient Strings (with Ballaké Sissoko), (1999), and Kulanjan (with Taj Mahal), (1999).

${ }^{13}$ Symmetric Orchestra band members would eventually get their break in the decade that followed, for those who endured the wait, with the group's internationally acclaimed release, Boulevard de l'Indépendence (2006).

${ }^{14}$ It is, perhaps, worth noting that Blondy recorded his own version of Marley's "War", titled, "La Guerre", on the album Dieu (1994), which preceded Grand Bassam Zion Rock.

\section{Acknowledgements}

This article began as a component of my doctoral research at Columbia University. I thank members of my graduate committee (Aaron Fox, Ana Maria Ochoa, Ellen Gray, Brian Larkin, and Gregory Mann) for their critical feedback and guidance at this stage. More recent versions of this essay were presented as public lectures at Ohio University (International Studies Forum) and the University of California at Santa Barbara (Interdisciplinary Humanities Center) in May and June of 2012. I thank the organizers of these events for the opportunity to present and develop this study. Special thanks go to David Novak and Brandon County for their longstanding critical and constructive engagement with my work, and for their friendship. Finally, I thank the Social Science Research Council, the Wenner-Gren Foundation, and the College of Arts and Sciences at The Ohio State University for generously supporting the research for this article. All song lyrics are transcribed from a live Triton Stars concert on 8 December 2006 at the Centre de Recherche Culturelle et Artistique in Bamako, Mali. I thank 
members of the group and their management for permitting me to record and use this material in this study.

\section{Bibliography}

Amselle, Jean-Loup (1978) Le conscience paysanne: la révolte de Ouolossébougou (juin 1968, Mali). Canadian Journal of African Studies / Revue Canadienne des Études Africaines 12 (3): 339-355.

Arnoldi, Mary Jo (2006) Youth Festivals and Museums: The Cultural Politics of Public Memory in Postcolonial Mali. Africa Today 52 (4): 55-76.

Askew, Kelly (2002) Performing the Nation: Swahili music and cultural politics in Tanzania. Chicago: University of Chicago Press.

Bamba, Sorry, and Prévost, Liliane (1996) De la tradition à la World Music, Paris: L'Harmattan.

Barchiesi, Franco (2012) Precarity as Capture: A Conceptual Reconstruction and Critique of the Worker-Slave Analogy, UniNomade 2.0.10 October, http://www.uninomade.org/precarity-as-capture Accessed: 3 Dec 2012.

Becker, Howard (1982) Art Worlds, Berkeley: University of California Press.

Cissé, Nana Mourkayrou and Traoré, Oualy Sékou (2001) Les aspects théoriques et pratiques de la lutte contre la contrefaçon au Mali, Master's Thesis, Faculté des Sciences Juridiques et Economiques, Mali: Université du Mali, Bamako.

Comaroff, Jean and John L. Comaroff Eds. (2006) Law and Disorder in the Postcolony, Chicago: The University of Chicago Press.

Couloubaly, Pascal Baba (2004) Le Mali d'Alpha Oumar Konaré: ombres et lumières d'une démocratie en gestation, Paris: L'Harmattan.

Counsel, Graeme-

(2006) Mande popular music and cultural policies in West Africa, Ph.D. dissertation, Melbourne: The University of Melbourne.

(2012) "Discography of Malian Vinyl Recordings," Radio Africa. 30 August, http://www.radioafrica.com.au/Discographies/Malian.html Accessed: 2 Dec 2012.

Diakité, Mandé Moussa (2006) La piraterie des oeuvres usicales dans le district de Bamako: cas du Dabanani, Master's Thesis, L'Institut National de la Jeunesse et des Sports, Mali: Bamako.

Diarrah, Cheick Oumar (1991) Vers La IIle Republique du Mali, L'Harmattan, Paris.

Diawara, Mamadou (1997) Mande Oral Popular Culture Revisited by the Electronic Media. In Karin Barber Ed. Readings in African popular culture. Bloomington: Indiana University Press. 40-48.

Diawara, Manthia (1997) "The song of the griot": Transition Vol. 74, pp. 16-30.

Durán, Lucy (1995) Jelimusow: The Superwomen of Malian Music. In Graham Furniss and Liz Gunner Eds. Power, Marginality and African Oral Literature. Cambridge: Cambridge University Press. 197-207.

Eyre, Banning (2000) In Griot Time: An American Guitarist in Mali. Philadelphia: Temple University Press.

Feld, Steven (2000) A Sweet Lullaby for World Music. Public Culture 12 (1): 45-71.

Foucault, Michel (2007) Security, Territory, Population: Lectures at the Collège de France, 1977-1978, New York: Palgrave Macmillan.

Guilbault, Jocelyne (2007) Governing Sound: The Cultural Politics of Trinidad's Carnival Musics. Chicago: The University of Chicago Press.

Guyer, Jane Ed. (1995) Money Matters. Portsmouth: Heinemann. 
Hammer, Joshua (2005) The Siren Song of Mali. The New York Times. 2 April, Section 5: 10-11.

Karaganis, Joe Ed. (2011) Media Piracy in Emerging Economies. Social Science Research Council.

Keïta, Cheick M. Chérif (2009) Salif Keïta: L'ambassadeur de la musique du Mali. Éditions Grandvaux. Brinon-sur-Sauldre.

Laing, Dave (2004) Copyright, Politics and the International Music Industry. In Simon Frith and Lee Marshall Eds. Music and Copyright ( $2^{\text {nd }}$ Edition). New York: Routledge. 70-88.

Larkin, Brian (2008) Signal and Noise: Media, Infrastructure, and Urban Culture in Nigeria. Durham: Duke University Press.

Latournerie, Anne (2001) Petite histoire des batailles du droit d'auteur. Multitudes 5. May, http://multitudes.samizdat.net/article.php3?id article=168 Accessed: 1 May 2012.

Lessig Lawrence (2004) Free Culture: The Nature and Future of Creativity. London: Penguin Books.

Maillot, Elodie (2002) Mali K7, l'usine à rêve. Radio France Internationale. 17 January, http://www.rfimusique.com/musiquefr/articles/060/article 13157.asp Accessed: 6 Dec 2007.

Mangin, André (1998) Malick Sidibé. Berlin: Helvetas.

McGovern, Mike (2011) Making War in Côte d'Ivoire. Chicago: University of Chicago Press

Ntahokaja, l'Abbé (1963) Réunion africaine d'étude sur le droit d'auteur. Brazzaville, 510 août 1963. Le Droit d'Auteur 76: 250-259.

Pauthier, Céline (2012) La musique guinéenne, vecteur du patrimoine national (des années 1950 à 1984). In Daouda Gary-Tounkara and Didier Nativel Eds. L'Afrique des saviors au sud du Sahara (XVle-XXle siècle): acteurs, supports, pratiques.

Paris: Karthala

Rhythmes 19 (1999) Fermeture pour cause de piraterie. 6 (4).

Rhythmes 20 (2000) La piraterie: l'ennemi à abattre. 7(1-2).

Sanankoua, Bintou (1990) La chute de Modibo Keïta, Editions. Paris: Chaka

Skinner, Ryan T.-

(2004) Determined Urbanites: Diasporic Jeliya in the $21^{\text {st }}$ Century. Mande Studies 6:139-62.

(2011) The Ethics of Ambiance, the Morality of the State: Popular Culture and Political Society in Bamako, 1956-1966. Paper presented at the annual meeting of the African Studies Association in Washington D.C., 19 November.

(2012a) Arists, Music Piracy, and the Crisis of Political Subjectivity in Contemporary Mali. Anthropological Quarterly 85 (3): 723-754.

(2012b) Cultural Politics in the Post-Colony: Music, Nationalism, and Statism in Mali, 1964-1975. Africa 82 (4): 511-534.

Tower, Craig (2005) 'Arajo Efemu': Local FM Radio and the Socio-Technical System of Communications in Koutiala, Mali. The Radio Joumal: International Studies in Broadcast and Audio Media 3 (1): 7-20.

Traoré, Richard (2004) Music Industry in Burkina Faso and Mali - The Case of Seydoni Production. In Stig-Magnus Thorsén Ed. Sounds of Change: Social and Political Features of Music in Africa. Stockholm: Sida. 107-119. 
Wooten, Stephen (Ed.) (2005) Wari Matters: Ethnographic Explorations of Money in the Mande World. Münster: LIT Verlag.

Yudicé, George (2004) The Expediency of Culture: The Uses of Culture in the Global Era, Durham: Duke University Press.

\section{Discography}

Blondy, Alpha, and the Solar System1994. Dieu, EMI France. Compact disc.

1996. Grand Bassam Zion Rock, EMI France. Compact disc.

Diabaté, Toumani, Keletigui Diabaté and Bassekou Kouyaté (1995) Djelika, Hannibal. Compact disc.

Diabaté, Toumani, and Ballaké Sissoko (1999) New Ancient Strings, Hannibal. Compact disc.

Diabaté, Toumani, and Taj Mahal (1999) Kulanjan, Hannibal. Compact disc.

Diabaté, Toumani, and the Symmetric Orchestra (2006) Boulevard de l'Indépendence. World Circuit, Nonesuch. Compact disc.

Epic, historical, political and propaganda songs of the Socialist government of Modibo Keita (1960-1968), Volume 1 \& 2. 1977. Albatross. VPA 8326. $33.3 \mathrm{rpm}$ disc.

Marley, Bob, and The Wailers. (1976) Rastaman Vibration, Island. $33.3 \mathrm{rpm}$ disc

Orchestre Régional du Mali. Mopti. Les meilleurs souvenirs de la 1ère Biennale Artistique et Culturelle de la Jeunesse, Bärenreiter-Musicaphon. BM 30 L 2602. $33.3 \mathrm{rpm}$ disc.

Panorama du Mali (1973) Mali Music, Mali 1002. 33.3 rpm disc.

Regard sur le passé à travers le present (1973) Mali Music, Mali 1001. 33.3 rpm disc.

\section{Interviews}

Dembelé, Panka (2007) Former member and director of the Orchestre National du Mali. Bamako, Mali. 3 May.

Diabaté, Djelimory Nfa (2006) Former member of the Ensemble Instrumental National du Mali. Bamako, Mali. 9 November.

Diabaté, Jeli Magan (2006) Former member of the Ensemble Instrumental National du Mali and VER participant. Bamako, Mali. 23 November.

Diakité, Mande Moussa (2007) Adjunct Director at the Bureau Malien du Droit d'Auteur. Bamako, Mali. 21 January.

Diarra, Bourama (2008) Representative of VER participants at the Malian Labor Exchange. Bamako, Mali. 16 December.

Fofana, Amadou (2008) Former member of the Badema National (Malian National Orchestra) and VER participant. Bamako, Mali. 15 August.

Maiga, Bruno. (2011) Former administrative director of the Théatre National du Mali. Bamako, Mali. 17 August.

Traoré, Amadou (2007) Former member and director of the Orchestre National du Mali, Section B. Bamako, Mali. 26 June. 